\title{
PENGARUH KOLEKTIVISME, PERCEIVED CONSUMER EFFECTIVENESS, DAN KEPEDULIAN LINGKUNGAN TERHADAP PERILAKU PEMBELIAN RAMAH LINGKUNGAN
}

\author{
Oleh \\ Tri Widodo \\ Dosen STIE AMA Salatiga \\ Rina Sari Qurniawati \\ Dosen STIE AMA Salatiga
}

\begin{abstract}
These days, most consumers have realized that their purchasing behavior has a direct impact on the incidence of various environmental problems. Consumers adapt to new situations which threaten this by considering environmental issues when they are shopping. There are several factors that make the driving behavior of the community began to show the purchase of products that are environmentally friendly.

This research design is the design of a survey conducted in order to test the influence of collectivism, Perceived Consumer Effectiveness (PCE), and Environmental Concern on environmentally friendly purchasing behavior. Survey conducted on 40 respondents with at least one high school.

Data analysis was performed using multiple linear regression. The results showed that: 1) collectivism significant influence on the purchasing behavior of environmental friendly; 2) Perceived Consumer Effectiveness (PCE) significant influence on the purchasing behavior of environmental friendly; 3) environmental awareness significant influence on the purchasing behavior of environmental friendly.
\end{abstract}

\section{Keywords : Sustainable Purchasing Behavior, Collectivism, PCE, Environmental} Concern, Multiple Linear Regression

\section{A. PENDAHULUAN}

Kesadaran masyarakat pada lingkungan terhadap ancaman terjadinya bencana yang diakibatkan kerusakan lingkungan meningkat. Bencana ini akan mengancam kehidupan dan anak keturunan mereka di masa mendatang. Perbaikan mutu kehidupan dan gaya hidup sehat telah mendorong masyarakat di berbagai negara dan mendorong gerakan gaya hidup sehat dengan tema global kembali ke alam atau back to nature. Gerakan ini didasari bahwa segala sesuatu yang berasal dari alam adalah baik dan berguna serta menjamin adanya keseimbangan (Junaedi, 2008).

Kepedulian terhadap lingkungan telah berkembang melalui beberapa tahapan yang nyata. Dari tahun 1960-an pergerakan tentang ekologi hanya fokus pada polusi dan perlindungan terhadap energi, akan tetapi akhir-akhir ini isu-isu lingkungan telah dijadikan sebagai sebuah sumber dari keunggulan bersaing dalam bisnis dan politik, individu, dan kepedulian sosial yang meningkat secara nyata. Dalam perkembangannya, lingkungan menjadi permasalahan terbesar yang 
dihadapi perusahaan bisnis dan masyarakat tahun 1990-an, sehingga disebut sebagai "the decade of environment"(Fotopoulus dan Krystallis, 2002).

Sedikit dari bukti empiris yang tersedia mendukung bahwa perilaku dan kepercayaan pro lingkungan diwujudkan dalam perilaku sadar terhadap lingkungan (Hume, 1991). Perilaku kepedulian terhadap lingkungan berbeda dengan perilaku pembelian konsumen secara umum. Perilaku pembelian secara umum biasanya didorong oleh sebuah penilaian tentang manfaat dan harga yang menurut konsumen relevan untuk dibeli. Akan tetapi sebaliknya, perilaku ramah lingkungan sepertinya tidak memberikan peningkatan dan kepuasan instan pribadi konsumen, tetapi lebih kepada orientasi outcome masa depan (e.g., lingkungan yang lebih bersih) yang sering memberikan keuntungan kepada lingkungan secara keseluruhan (Kim dan Choi, 2005).

Berdasarkan uraian diatas, akan disampaikan hasil penelitian yang bertujuan untuk menguji pengaruh kolektivisme, Perceived Consumer Effectiveness, dan kepedulian lingkungan terhadap perilaku pembelian ramah lingkungan.

\section{B. RUMUSAN MASALAH}

Berdasarkan uraian di atas, maka rumusan masalah dalam ini penelitian adalah :

1. Apakah Kolektivisme berpengaruh positif pada perilaku pembelian ramah lingkungan?

2. Apakah Perceived Consumer Effectiveness (PCE) berpengaruh positif pada perilaku pembelian ramah lingkungan?

3. Apakah kepedulian lingkungan berpengaruh positif pada perilaku pembelian ramah lingkungan?

Sesuai dengan permasalahan penelitian, maka tujuan penelitian ini adalah menemukan bukti empiris adanya pengaruh Kolektivitas, Perceived Consumer Effectiveness (PCE), dan Kepedulian Lingkungan pada perilaku pembelian ramah lingkungan.

Hasil Penelitian diharapkan akan memberi manfaat bagi peneliti untuk dapat lebih menperdalam ilmu pemasaran dan perilaku konsumen, khususnya faktor-faktor yang menjadi pendorong konsumen melakukan pembelian produk ramah lingkungan, bagi praktisi diharapkan dapat memberikan sumbangan informasi dan pemikiran bagi praktisi (pemasar) untuk menjadi bahan pertimbangan bagaimana seharusnya mempelajari perilaku pembelian yang ramah lingkungan. Dengan demikian pemasar dapat menerapkan startegi-strategi khusus yang dapat meningkatkan penjualan produk hijau, dan bagi akademisi diharapkan dapat berguna sebagai bahan pertimbangan bagi penelitian selanjutnya, terutama untuk penelitian yang berkaitan dengan faktor-faktor yang mendorong konsumen berperilaku ramah lingkungan, khususnya mereka melakukan pembelian produk ramah lingkungan.

\section{PAPARAN TEORITIS}

\section{Perilaku Pembelian Ramah Lingkungan}

Pemenuhan kebutuhan konsumen merupakan tantangan yang harus dihadapi oleh setiap pemasar. Dengan terjadinya krisis lingkungan menuntut adanya peningkatan kepedulian sosial dan pengetahuan lingkungan bagi 
konsumen. Konsumen yang memutuskan untuk melakukan suatu pembelian produk tertentu dipengaruhi oleh berbagai faktor yang sangat kompleks. Pada umumnya suatu peristiwa konsumsi dipandang sebagai proses ekonomik, namun pada kenyataannya konsumsi juga merupakan suatu proses sosial dan budaya yang diindikasikan melalui simbol-simbol (Peattie, dalam Junaedi 2003).

Environmentally Conscious Consumer Behavior (ECCB) adalah perilaku konsumen yang didasarkan atas timbulnya kesadaran akan dampak lingkungan yang berhubungan dengan sebuah produk atau jasa dan sebuah keinginan untuk mengurangi adanya dampak kerusakan. Banyak peneliti di bidang psikologi konsumen dan penelitian pemasaran telah mendemonstrasikan pertumbuhan ECCB yang substansial dalam sebuah lingkup pasar. Telah ditunjukkan pula melalui berbagai studi kasus dimana pengembang produk dan pemasar mengutamakan perilaku positif dan membedakan produk mereka dalam istilah yang berkarakter "ramah lingkungan".

\section{Kolektivisme}

Berasal dari penelitian Hofstede (1980), pengertian individualisme versus kolektivisme menggambarkan perbedaan dalam keyakinan dasar bahwa individu memegang teguh rasa hormat ketika mereka berinteraksi dengan orang lain, prioritas tujuan kelompok, dan merasakan pentingnya persatuan dengan orang lain. Secara umum, orang-orang dari budaya individualistis cenderung independen dan berorientasi pada diri mereka sendiri sedangkan yang dari kolektivisme, budaya merupakah hal yang lebih kepada saling tergantung dan berorientasi kelompok. Individualisme ditandai dengan kemandirian, kepercayaan diri, kebebasan pilihan, dan tingkat kompetisi yang tinggi (Triandis 1989), sedangkan kolektivisme menekankan saling ketergantungan, harmoni dalam kelompok, keamanan keluarga, orientasi tujuan yang berkelompol, hierarki sosial, kerjasama, dan tingkat persaingan yang rendah (Hosfstede 1980; Triandis 1995).

Individualistis atau orientasi kolektif telah ditemukan dapat mempengaruhi berbagai perilaku sosial. Demikian juga, tingkat kecenderungan seseorang pada individualisme atau kolektivisme muncul untuk mempengaruhi motivasi mereka agar terlibat dalam perilaku sadar lingkungan. McCarty dan Shrum (1994, 2001) menemukan dampak positif dari kolektivisme pada keyakinan konsumen tentang daur ulang dan perilaku daur ulang. Artinya, orang kolektivis lebih cenderung terlibat dalam daur ulang perilaku karena mereka cenderung lebih kooperatif, lebih bersedia untuk membantu orang lain, dan menekankan tujuan kelompok lebih dari yang pribadi daripada orang individualistis. Sebaliknya, orang dengan kecenderungan individualistis cenderung untuk melihat daur ulang kurang penting (McCarty dan Shrum 2001) dan kecil kemungkinannya untuk berpartisipasi dalam perilaku untuk pemelihara sumber daya (Dunlap dan Van Liere 1984) daripada orang yang memiliki tingkat kolektivitas tinggi. Hasil serupa juga ditemukan untuk komitmen ekologi (Li 1997),

\section{Perceived Consumer Effectiveness (PCE)}


Perceived Consumer Effectiveness (PCE) mengacu sejauh mana orang-orang percaya bahwa tindakan mereka membuat perbedaan dalam memecahkan masalah (Ellen, Weiner, dan Cobb-Walgren 1991). PCE, yang didefinisikan sebagai "evaluasi diri dalam konteks masalah" (Berger dan Corbin,1992), berbeda dari sikap yang mencerminkan evaluasi akan sebuah masalah (Tesser dan Shaffer, 1990).

Ellen, Weiner dan Cobb-Walgren (1991) menunjukkan bahwa PCE untuk isu lingkungan juga berbeda dari kepedulian atau sikap terhadap lingkungan dan membuat kontribusi yang unik untuk memprediksi perilaku sadar lingkungan seperti pembelian hijau. Kekhawatiran konsumen tentang isu-isu lingkungan mungkin tidak mudah diterjemahkan ke dalam perilaku pro lingkungan hidup, namun, individu yang mempunyai sebuah keyakinan yang kuat bahwa mereka sadar lingkungan perilaku akan menghasilkan hasil yang positif. Sehingga meraka akan lebih mungkin terlibat dalam perilaku tersebut dalam mendukung kekhawatiran mereka untuk lingkungan. Dengan demikian, keyakinan self-efficacy mungkin mempengaruhi kemungkinan melakukan perilaku pembelian hijau.

PCE ditentukan oleh pengetahuan baik oleh pengalaman langsung maupun tidak langsung dan bervariasi dengan individu sebagai pengetahuan pribadi mereka dan pengalaman berbeda (Brown 1979; Thompson 1981). Beberapa orang percaya bahwa tindakan mereka mengakibatkan hasil tertentu sehingga dapat membawa perubahan, sementara yang lain memiliki sedikit kepercayaan mereka memiliki kemampuan untuk membuat perbedaan. PCE merupakan sebuah situasi atau isu yang spesifik dan kepercayaan pribadi ini mungkin terbentuk di bawah pengaruh orientasi nilai yang lebih umum dan abstrak.

\section{Kepedulian Lingkungan}

Hal mendasar untuk penelitian lingkungan adalah kepedulian konsumen terhadap lingkungan (Hines et al 1987.). Kepedulian lingkungan menunjukkan orientasi umum individu terhadap lingkungan dan tingkat perhatian individu terhadap isu lingkungan telah ditemukan menjadi prediktor lingkungan yang berguna untuk menlilai perilaku sadar lingkungan yang dimulai dari perilaku daur ulang (Arbuthnot dan Ligg 1975; Kellgren dan Wood 1986; Simmons dan Widmar 1990) sampai pada perilaku pembelian hijau (Chan 1996; Donaton dan Fitzgerald 1992; 1990 Kerr, Ottman 1993; Schlossberg 1992). Misalnya, konsumen dengan kepedulian yang kuat terhadap lingkungan lebih cenderung membeli produk sebagai hasil dari klaim lingkungan mereka (Mainieri et al 1997.) Dibandingkan mereka yang kurang peduli tentang masalah lingkungan.

Kepedulian lingkungan seorang individu juga telah ditemukan berkaitan dengan kepercayaan dan nilai yang mendasar dari diri seseorang (Stern et al., 1995) dan dapat ditentukan oleh orientasi nilai inti individui. Sebagai contoh, masalah lingkungan secara positif dipengaruhi oleh nilai-nilai altruistik termasuk biospherism, namun negatif berhubungan dengan nilai-nilai egois (Schultz dan Zelezny 1998). Demikian pula, 
kolektivisme mungkin berhubungan dengan masalah lingkungan karena penekanannya pada kesejahteraan anggota kelompok.

Hubungan antara sikap dan perilaku merupakan suatu hubungan yang telah dieksplorasi dalam berbagai konteks. Dalam literature lingkungan, untuk mengeksplorasi hubungan antara konstrak attitudinal, konsern lingkungan, dan berbagai pengukuran keperilakuan dan atau observasi. Studi sebelumnya menunjukkan bahwa kepedulian lingkungan sebagai hubungan dengan perilaku ramah lingkungan yang berkorelasi positif. Dalam mengembangkan skala objektif untuk mengukur dan memahami kepedulian lingkungan, Maloney dan Ward (1973) dalam Chan dan Lau (2000) mengkonseptualisasikan sebagai sejumlah pengetahuan (ecological knowledge), tingkat emosionalitas (ecological affect) dan tingkat verbal (ecological intention) dan komitmen actual (ecological behavior) terhadap isu lingkungan.

Gambar 1

Skema Rerangka Pemikiran

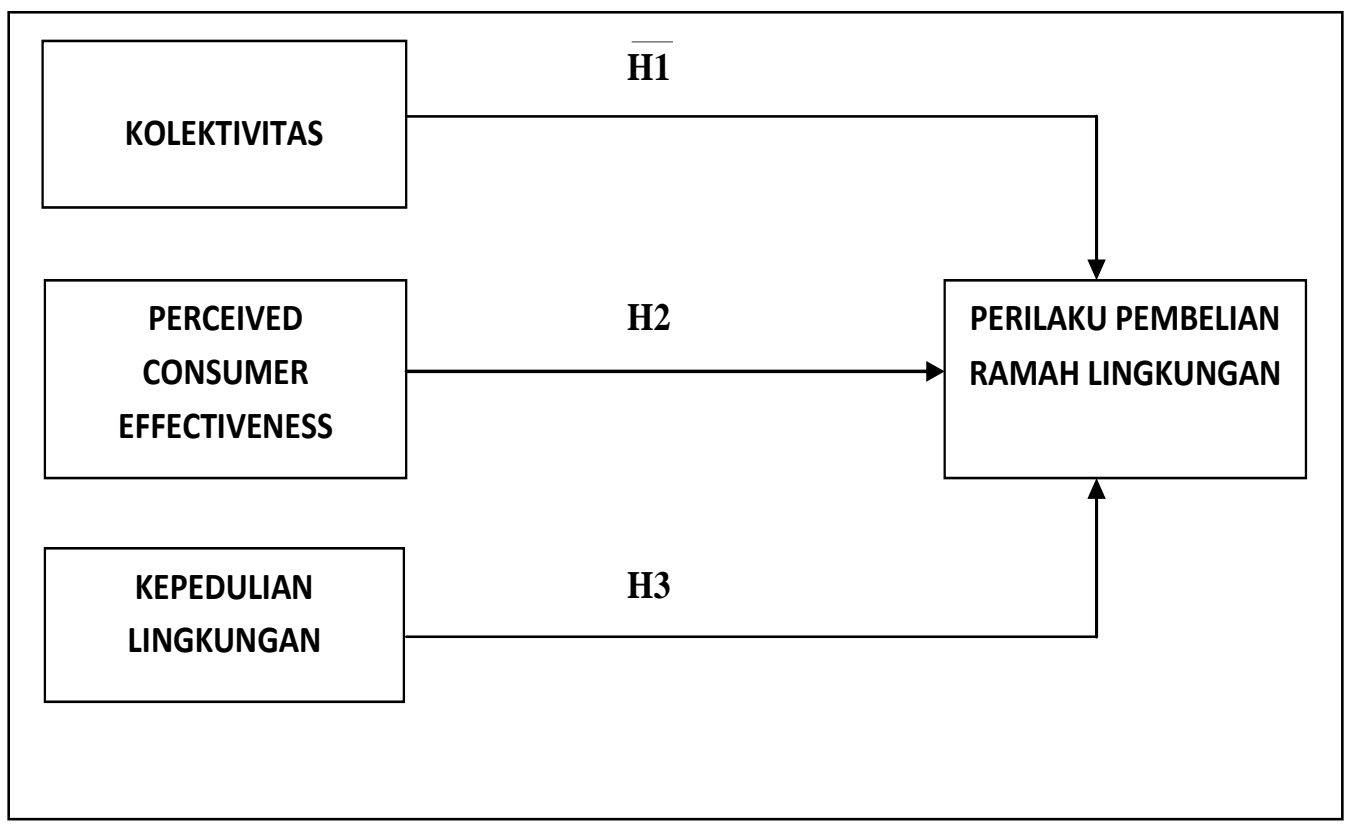

\section{E. METODE PENELITIAN}

Penelitian ini dilakukan dengan menggunakan metode survey dengan tipe self-administered questionnaires. Peneliti mengumpulkan data primer secara langsung dengan membagikan kuesioner untuk diisi oleh responden yang memiliki kriteria sebagaimana yang telah ditentukan sebelumnya.

Metode pemilihan sampel (sampling) dalam penelitian ini dilakukan secara non probability dengan teknik purposive sampling. Selain karena keterbatasan waktu, tenaga, dan biaya, alasan utama pengambilan sampel dilakukan secara non probability ialah karena dalam penelitian ini peneliti tidak memiliki list anggota populasi dari konsumen yang ramah lingkungan. Teknik purposive sampling atau sampel bersyarat digunakan berdasarkan pada kriteria pendidikan responden minimal adalah Sekolah Menengah Atas. 


\section{a. Definisi Operasional Variabel}

1. Perilaku pembelian ramah lingkungan, variabel dependen ini mengukur tingkat dimana responden individu yang membeli barang atau jasa dipercaya memiliki dampak positif yang lebih atau dampak negatif yang minimal terhadap lingkungan, (Straughan dan Roberts, 1999).

2. Kolektivisme didefinisikan sebagai teori dan praktek yang mendahulukan kepentingan kelompok dibandingkan dengan individu sebagai unit yang mendasarkan pada kepedulian politik, sosial, dan ekonomi.

3. Perceived consumer effectiveness (PCE) mengacu pada sejauh mana orangorang percaya tindakan mereka membuat perbedaan dalam menyelesaikan masalah (Ellen et al., 1991). PCE didefinisikan sebagai "evaluasi diri dalam sebuah konteks masalah" (Berger dan Corbin, 1992), yang berbeda dari sebuah sikap yang merefleksikan evaluasi dari sebuah isu (Tesser dan Shaffer, 1990).

4. Konsep kepedulian lingkungan disusun dari 2 dimensi yaitu: pertama, sikap seorang pembeli harus mengekspresikan kepedulian terhadap ekologi dan kedua, dia harus mengindikasikan perilaku pembelian yang konsisten dengan pembiayaan sistem ekologi (Kinnear et al., 1974).

\section{F. Metode Analisis Data}

Analisa data dilakukan dengan menggunakan metode analisa kuantitatif yaitu dengan mengumpulkan, mengolah, dan menginterpretasikan data yang diperoleh sehingga memberi keterangan yang benar dan lengkap untuk pemecahan masalah yang dihadapi. Metode analisis data yang digunakan dalam penelitian ini adalah model regresi sederhana dengan menggunakan bantuan software SPSS for window 12.5. Ada dua jenis pengujian yang dapat dipakai dalam penelitian ini, yaitu uji asumsi klasik dan pengujian hipotesis.

\section{Pengujian Asumsi Klasik}

a) Uji normalitas

Uji normalitas berguna pada tahap awal dalam metode pemilihan analisis data. Jika data normal, maka digunakan statistik parametrik, dan jika data tidak normal, gunakan statistik nonparametrik. Tujuan uji normalitas data ini adalah untuk mengetahui apakah dalam model regresi variabel pengganggu atau residual memiliki distribusi normal.

b) Uji Multiko linearitas

Pengujian ini bertujuan untuk menguji apakah model regresi ditemukan adanya korelasi diantara variabel independen. Model regresi yang baik seharusnya tidak terjadi korelasi diantara variabel independen (Ghozali, $2005: 91)$.

c) Uji Heterokedastisitas

Pengujian ini bertujuan untuk melihat apakah dalam model regresi terjadi ketidaksamaan variabel dari residual satu pengamatan ke pengamatan lain. Jika variabel residual tersebut tetap, maka disebut homoskedastisitas dan jika berbeda disebut heterokedastisitas.

\section{Metode Regresi Linier Berganda}

Regresi linear merupakan suatu metode analisis statistik yang mempelajari pola hubungan antara dua atau lebih variabel. Pada kenyataan 
sehari-hari sering dijumpai sebuah kejadian dipengaruhi oleh lebih dari satu variabel. Analisis regresi linier berganda memberikan kemudahan bagi pengguna untuk memasukkan lebih dari satu variabel prediktor hingga $\mathrm{p}$ variabel prediktor dimana banyaknya $\mathrm{p}$ kurang dari jumlah observasi (n). Regresi linier berganda, digunakan untuk mengetahui independen variabel mana saja (Kolektivisme, Perceived Consumer Effectiveness (PCE), dan Kepedulian Lingkungan), yang merupakan prediktor variabel dependen (Perilaku pembelian ramah lingkungan).

$$
\mathbf{Y}=\alpha+\beta_{1} X_{1}+\beta_{2} X_{2}+\beta_{3} X_{3}+\varepsilon
$$

Keterangan:

Y: Perilaku Pembelian Ramah Lingkungan

$\alpha:$ Konstanta

$\beta_{1}$ : Koefisien regresi

$\mathrm{X}_{1}$ : Kolektivisme

$\mathrm{X}_{2}$ : Perceived Consumer Effectiveness (PCE)

$\mathrm{X}_{3}$ : Kepedulian lingkungan

\section{G. HASIL PENELITIAN DAN PEMBAHASAN}

Analisis hasil penelitian tentang variabel perilaku pembelian ramah lingkungan, variabel kolektivitas, variabel Perceived consumer effectiveness, dan variabel kepedulian lingkungan. Analisis dimulai dengan karakteristik partisipan, uji hipotesis penelitian, dan analisis pembahasan di bagian akhir.

\section{Karakteristik Partisipan}

Dalam penelitian ini, kuesioner diberikan kepada 40 responden dan kuesioner yang diterima kembali sejumlah 37 kuesioner. Setelah melalui analisis data, ditemukan bahwa data yang memenuhi untuk dianalisis lebih lanjut adalah sebanyak 36 responden. Adapun karakteristik partisipan berdasarkan jenis kelamin dapat dilihat dari tabel 4.1. Dari 37 data, responden pria berjumlah 10 orang $(27 \%)$ dan responden wanita berjumlah 27 orang (73\%).

Sementara, berdasarkan usia, dari 37 data terkumpul sebanyak 15 responden yang berusia 22-26 tahun (40,5\%), usia 17-21 tahun sebanyak 7 responden $(18,9 \%)$, usia $27-31$ tahun sebanyak 6 responden $(16,2 \%)$, usia 57 61 tahun 1 responden (2.8\%) dan sisanya usia 32-36 tahun, 37-41 tahun, 42-46 tahun, dan 47-51 tahun masing-masing 2 responden $(5,4 \%)$.

Terakhir karakteristik responden berdasarkan pendidikan, sebanyak 11 responden berpendidikan Sarjana (29,7\%), 17 responden berpendidikan SMA (45.9\%), 7 orang berpendidikan Diploma (18,9\%), dan 2 responden berpendidikan Pasca Sarjana (5,4\%).

\section{Hasil Uji Validitas dan Reliabilitas}

Pengujian validitas dilakukan dengan Confirmatory Factor Analysis (CFA). CFA ini perlu dilakukan karena dapat menguji apakah suatu konsturk mempunyai unindimensionalitas atau apakah indikator-indikator yang digunakan dapat mengkonfirmasi sebuah konstruk atau variabel. Indikator- 
indikator masing-masing konstruk yang memiliki loading factor yang signifikan menunjukkan bahwa indicator tersebut merupakan suatu kesatuan alat ukur yang mengukur konstruk yang sama dan dapat memprediksi dengan baik konstruk yang seharusnya diprediksi (Hair et al., 1998). Uji validitas dilakukan dengan menggunakan confirmatory factor analysis dengan software SPSS.

Tabel 1

KMO and Bartlett's Test

\begin{tabular}{|ll|r|}
\hline \multicolumn{2}{|l|}{ Kaiser-Meyer-Olkin Measure of } \\
Sampling Adequacy. & .549 \\
Bartlett's Test of & Approx. Chi- \\
Sphericity & Square & 226.994 \\
& Df & 120 \\
& Sig. & .000 \\
\hline
\end{tabular}

Sumber: lampiran

Tabel 2

Rotated Component Matrix

\begin{tabular}{|l|r|r|r|r|}
\hline & \multicolumn{4}{|c|}{ Component } \\
\cline { 2 - 5 } & 1 & 2 & \multicolumn{1}{c|}{3} & \multicolumn{1}{c|}{4} \\
\hline PPRL1 & .402 & .499 & .106 & -.043 \\
PPRL2 & .104 & .455 & .138 & .520 \\
PPRL4 & .348 & .730 & -.072 & .196 \\
KOLEK1 & -.126 & .760 & .361 & -.158 \\
KOLEK2 & .187 & .227 & .770 & -.093 \\
KOLEK3 & .053 & .732 & .048 & .012 \\
KOLEK4 & .045 & -.041 & .803 & .201 \\
PCE1 & .425 & .083 & .127 & -.528 \\
PCE2 & .064 & -.011 & .070 & .817 \\
PCE3 & .019 & .592 & -.448 & .102 \\
PCE4 & .716 & .302 & -.090 & .095 \\
KL1 & .863 & .067 & .203 & .000 \\
KL2 & .755 & .173 & .187 & .143 \\
KL3 & .745 & -.169 & -.064 & -.260 \\
\hline
\end{tabular}

Sumber: data primer, diolah 2015

Dengan melihat uji KMO dan Barlett test nilainya adalah $>0,50$, berarti dapat dilakukan analisis faktor. Seperti terlihat dari analisis faktor pada tabel semua item menunjukkan vaditas diatas 0,40 . Hal ini menandakan bahwa instrument yang digunakan dalam penelitian ini benar-benar mengukur hal yang sebenarnya (Sekaran, 2003). 
Selanjutnya, pengujian reabilitas setiap konstruk dilakukan dengan menggunakan koefisien Cronbach's Alpha. Dari hasil pengujian reabilitas didapatkan bahwa nilai Cronbach's Alpha untuk perilaku konsumen ramah lingkungan dan kepedulian lingkungan lebih besar dari 0,60, sedangkan pada variabel perceived consumer effectiveness dan orientasi politik Cronbach's Alpha kurang dari 0,60.

Tabel 3

Uji Reliabilitas

\begin{tabular}{|c|c|c|c|c|}
\hline No & Variabel & $\begin{array}{l}\text { Corrected item- } \\
\text { Total Correlation }\end{array}$ & $\begin{array}{l}\text { Cronbach's } \\
\text { Alpha }\end{array}$ & Keterangan \\
\hline 1 & $\begin{array}{l}\text { Perilaku Pembelian Ramah } \\
\text { Lingkungan } \\
\text { PPRL1 } \\
\text { PPRL2 } \\
\text { PPRL3 } \\
\text { PPRL4 } \\
\end{array}$ & $\begin{array}{l}0.4883 \\
0.4771 \\
0.6091 \\
0.6713 \\
\end{array}$ & 0.7648 & Reliabel \\
\hline 2 & $\begin{array}{l}\text { Kolektivisme } \\
\text { Kolek1 } \\
\text { Kolek2 } \\
\text { Kolek3 } \\
\text { Kolek4 }\end{array}$ & $\begin{array}{l}0.5095 \\
0.4667 \\
0.2922 \\
0.3111\end{array}$ & 0.6076 & Reliabel \\
\hline 3 & $\begin{array}{l}\text { Perceived Consumer Effectiveness } \\
\text { PCE1 } \\
\text { PCE2 } \\
\text { PCE3 } \\
\text { PCE4 }\end{array}$ & $\begin{array}{c}-0.1094 \\
0 \\
0.0779 \\
0.3674\end{array}$ & 0.1304 & $\begin{array}{l}\text { Tidak } \\
\text { Reliabel }\end{array}$ \\
\hline 4 & $\begin{array}{l}\text { Kepedulian Lingkungan } \\
\text { KL1 } \\
\text { KL2 } \\
\text { KL3 } \\
\text { KL4 }\end{array}$ & $\begin{array}{c}0.69 \\
0.877 \\
0.6283 \\
0.3096\end{array}$ & 0.7217 & Reliabel \\
\hline
\end{tabular}

\section{Hasil Uji Asumsi Klasik}

Sebelum melakukan analisis dengan menggunakan analisis regresi, terlebih dahulu perlu dilakukan uji asumsi terhadap data penelitian. Uji asumsi yang dilakukan dalam penelitian ini meliputi uji normalitas sebaran dan uji linieritas.

a. Hasil Uji Normalitas

Uji normalitas bertujuan untuk menguji apakah dalam sebuah model regresi, variabel dependen, variabel independen atau keduanya mempunyai distribusi normal atau tidak. Pengujian normalitas dilakukan terhadap masing-masing variabel dari model regresi dengan menggunakan 
uji One Sample Kolmogorov-Smirnov Test. Data dikategorikan terdistribusi normal jika menghasilkan nilai asymptotic significance > $\alpha=5 \%$. Hasil perhitungan One Sample Kolmogorov-Smirnov Test pada tabel 4 menghasilkan nilai Asymptotic significance sebesar 0,424 atau lebih besar dari 0,05. Berdasarkan hasil tersebut maka dapat disimpulkan bahwa model regresi telah memenuhi asumsi kenormalan.

Tabel 4

One-Sample Kolmogorov-Smirnov Test

\begin{tabular}{|ll|r|}
\hline & & \multicolumn{1}{|c|}{ PPRL } \\
\hline $\mathrm{N}$ & & 37 \\
Normal & Mean & 15.7568 \\
Parameters(a,b) & Std. Deviation & 2.26575 \\
Most Extreme & Absolute & .144 \\
Differences & Positive & .144 \\
& Negative & -.099 \\
Kolmogorov-Smirnov Z & .878 \\
Asymp. Sig. (2-tailed) & .424 \\
\hline
\end{tabular}

b. Hasil Uji Multikolinieritas

Uji multikolinearitas digunakan untuk menguji adanya korelasi antar variabel independen. Metode yang digunakan untuk mendeteksi adanya multikolinearitas adalah dengan menggunakan nilai VIF (variance inflation factor). Hasil uji gejala multikolinieritas disajikan pada tabel 5 berikut ini

Tabel 5

Hasil Uji Gejala Multikolinieritas

\begin{tabular}{|l|l|l|l|}
\hline No & Variabel & Tolerance & VIF \\
\hline X1 & KOLEK & 0,966 & 1,036 \\
\hline X2 & PCE & 0,909 & 1,100 \\
\hline X3 & KL & 0,940 & 1,064 \\
\hline
\end{tabular}

Hasil pengujian pada Tabel 5, semua variabel independen dalam model regresi menghasilkan nilai VIF $<10$ dan nilai tolerance $\geq 0,1$. Berdasarkan hasil tersebut maka dapat disimpulkan tidak terdapat gejala multikolinieritas antar variabel independen dalam model regresi.

c. Hasil Uji Heteroskedastisitas

Pengujian terhadap gejala heteroskedastisitas dilakukan dengan menggunakan Uji Park, yaitu dengan cara meregresikan nilai absolute unstandardized residual terhadap variabel independen dalam model regresi. Model regresi dinyatakan bebas dari gejala heteroskedastisitas apabila koefisien 37 parameter beta dari persamaan regresi tersebut secara statistik 
tidak signifikan (Ghozali, 2005:108). Hasil uji dengan menggunakan Uji Park disajikan pada gambar 2 sebagai berikut:

\section{Gambar 2}

\section{Hasil Uji Heteroskedastisitas}

\section{Scatterplot}

Dependent Variable: PPRL

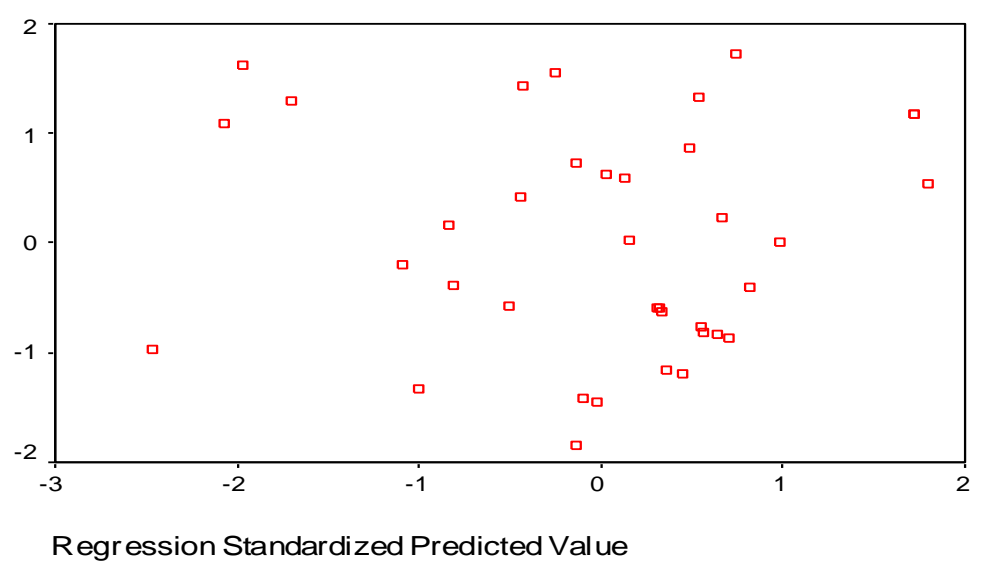

Hasil uji pada Gambar di atas, diketahui bahwa titik-titik (data) menyebar secara acak, tidak membentuk sebuah pola tertentu yang jelas, serta tersebar baik di atas maupun di bawah angka 0 pada sumbu Y. Dengan demikian, maka berarti tidak terjadi Heteroskedastisitas pada model regresi, sehingga model regresi layak dipakai untuk memprediksi variabel terikat (PPRL) berdasarkan ketiga variabel bebas yang digunakan (KOLEK, PCE dan KL) tersebut.

\section{Pengujian Hipotesis Penelitian}

Pada bagian ini model regresi berganda diterapkan untuk menguji variabel independen yaitu kolektivisme, Perceived Consumer Effectiveness, dan kepedulian lingkungan pada variabel dependen yaitu perilaku pembelian ramah lingkungan. Pada model regresi berganda ini digunakan SPSS 11.5 for Windows dan pada regresi menggunakan metode enter. Metode enter adalah metode yang memasukkan semua variabel independen kedalam persamaan regresi. Maka dapat ditulis model regresi sebagai berikut

Tabel 6

Persamaan Regresi Berganda

\begin{tabular}{|c|r|r|r|}
\hline Variabel & \multicolumn{1}{|l|}{$\beta$} & $\mathrm{t}_{\text {hitung }}$ & \multicolumn{1}{|l|}{ Sig } \\
\hline Konstan & 1,301 & & \\
X1 & 0,371 & 2,486 & 0,018 \\
X2 & 0,461 & 2,075 & 0,046 \\
X3 & 0,106 & 0,640 & 0,526 \\
\hline $\mathrm{R}^{2}=$ & 0,304 & & \\
\hline
\end{tabular}


Perilaku Pembelian Ramah Lingkungan $=1,301+0,371$ kolektivisme $+0,461 \mathrm{PCE}$

$+0,106$ Kepedulian Lingkungan $+\varepsilon$

Untuk menentukan besarnya kontribusi suatu variabel independen (X) terhadap variabel dependen (Y) dapat digunakan koefisien determinasi. Koefisien determinasi secara simultan dapat dilihat dalam tabel model summary sebagai berikut:

Tabel 7

\section{Koefisien Determinasi}

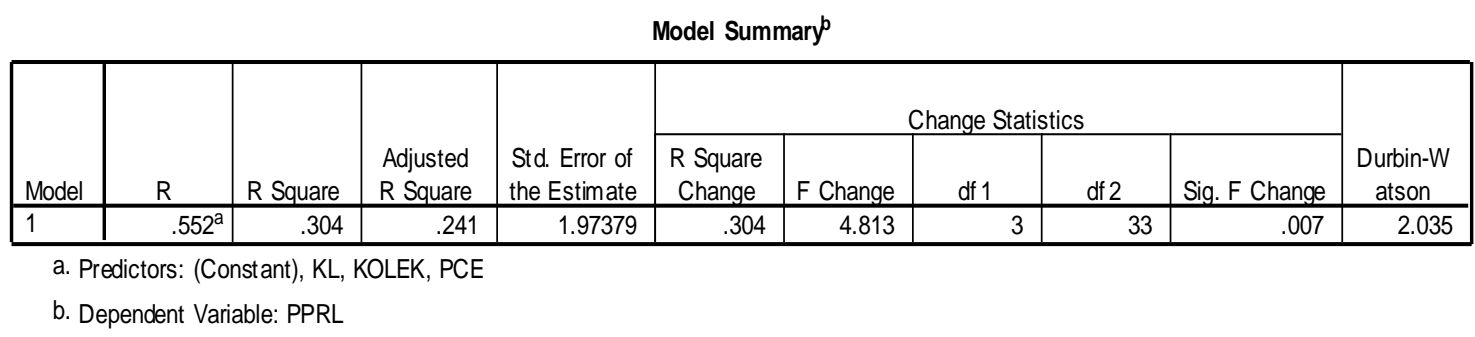

Dari tabel 7 diatas dapat disimpulkan bahwa nilai koefisien determinasi $\left(\mathrm{R}^{2}\right)$ secara simultan adalah sebesar 0,304 , hal ini berarti $30,40 \%$ variabel Perilaku pembelian ramah lingkungan dipengaruhi oleh variasi dari ketiga variabel independen Kolektivisme, Perceived Consumer Effectiveness, dan Kepedulian Lingkungan. Sedangkan sisanya sebesar 69,60\% dipengaruhi oleh variabel lain yang tidak diteliti dalam penelitian ini. Dan dari nilai adjusted $R$ square hasilnya adalah 0,241 ini artinya bahwa hasil regresi variabel Kolektivisme, Perceived Consumer Effectiveness, dan Kepedulian Lingkungan dapat menerangkan Perilaku Konsumen Ramah Lingkungan sebesar 24,1\%.

\section{a. Uji F}

Tabel 8

Uji Statistik F

\begin{tabular}{|l|r|r|r|r|l|}
\hline Model & \multicolumn{1}{|c|}{$\begin{array}{c}\text { Sum of } \\
\text { Squares }\end{array}$} & \multicolumn{1}{c|}{ Df } & Mean Square & F & Sig. \\
\hline Regression & 56.248 & 3 & 18.749 & 4.813 & $.007(\mathrm{a})$ \\
& 128.563 & 33 & 3.896 & & \\
Residual & 184.811 & 36 & & & \\
Total & & & & & \\
\hline
\end{tabular}


Dari uji ANOVA atau F test didapat nilai F Hitung sebesar 4, 813 dengan probabilitas 0,007. Karena probabilitas jauh lebih kecil dari 0,05, maka model regresi dapat digunakan untuk memprediksi Perilaku Pembelian Ramah Lingkungan atau dapat dikatakan bahwa Kolektivisme, Perceived Consumer Effectiveness, dan Kepedulian Lingkungan secara bersama-sama berpengaruh terhadap Perilaku Pembelian Ramah Lingkungan.

a) Kolektivisme terhadap Perilaku Pembelian Ramah Lingkungan Prosedur pengujian hipotesis dilakukan dengan cara sebagai berikut: 1. Hipotesis

Ho: Kolektivisme berpengaruh negatif pada Perilaku Pembelian Ramah Lingkungan.

Ha: Kolektivisme berpengaruh positif pada Perilaku Pembelian Ramah Lingkungan

2. Hipotesis secara statistik

Ho: $\beta_{i}=0$

Ha: $\beta_{i} \neq 0$

3. Kriteria Uji

Tolak Ho jika nilai signifikansi lebih kecil dari $\alpha=5 \%$.

4. Keputusan

Karena hasil pada tabel 4.7 menunjukkan nilai signifikansi sebesar 0.018 (lebih kecil dari $\alpha=5 \%$ ), maka Ho ditolak. Hal ini menunjukkan bahwa Kolektivisme (X1) berpengaruh secara signifikan terhadap Perilaku Pembelian Ramah Lingkungan.

b) Perceived Consumer Effectiveness terhadap Perilaku Pembelian Ramah Lingkungan

Prosedur pengujian hipotesis dilakukan dengan cara sebagai berikut:

1. Hipotesis

Ho: Perceived Consumer Effectiveness berpengaruh negatif pada Perilaku Pembelian Ramah Lingkungan.

Ha: Perceived Consumer Effectiveness berpengaruh positif pada Perilaku Pembelian Ramah Lingkungan

2. Hipotesis secara statistik

Ho: $\beta_{\mathrm{i}}=0$

Ha: $\beta_{\mathrm{i}} \neq 0$

3. Kriteria Uji

Tolak Ho jika nilai signifikansi lebih kecil dari $\alpha=5 \%$.

4. Keputusan

Karena hasil pada tabel 4.9 menunjukkan nilai signifikansi sebesar 0.046 (lebih kecil dari $\alpha=5 \%$ ), maka Ho ditolak. Hal ini menunjukkan bahwa Perceived Consumer Effectiveness (X2) berpengaruh secara signifikan terhadap Perilaku Pembelian Ramah Lingkungan. 


\section{c) Kepedulian Lingkungan terhadap Perilaku Pembelian Ramah Lingkungan}

Prosedur pengujian hipotesis dilakukan dengan cara sebagai berikut:

1. Hipotesis

Ho: Kepedulian Lingkungan berpengaruh negatif pada Perilaku Pembelian Ramah Lingkungan.

Ha: Kepedulian Lingkungan berpengaruh positif pada Perilaku Pembelian Ramah Lingkungan

2. Hipotesis secara statistik

Ho: $\beta_{i}=0$

Ha: $\beta_{\mathrm{i}} \neq 0$

3. Kriteria Uji

Tolak Ho jika nilai signifikansi lebih kecil dari $\alpha=5 \%$.

4. Keputusan

Karena hasil pada tabel 4.9 menunjukkan nilai signifikansi sebesar 0.526 (lebih besar dari $\alpha=5 \%$ ), maka Ho diterima. Hal ini menunjukkan bahwa Kepedulian Lingkungan (X3) tidak berpengaruh secara signifikan terhadap Perilaku Pembelian Ramah Lingkungan.

\section{Pembahasan}

Dari pengujian hipotesis 1 diperoleh hasil bahwa terdapat pengaruh kolektivisme pada perilaku pembelian ramah lingkungan. Individu kolektivis yang menghargai adanya tujuan kelompok dan kerja sama mungkin mempunyai motivasi yang tinggi untuk membuat pilihanpilihan tindakan pro lingkungan hidup dengan keyakingan tinggi bahwa perilaku mereka akan membuat perbedaan dalam mengurangi masalahmasalah tentang lingkungan hidup.

Hasil pengujian hipotesis 2 menunjukkan hasil bahwa terdapat pengaruh Perceived Consumer Effectiveness pada perilaku pembelian ramah lingkungan. Teori dilema sosial dapat digunakan untuk memprediksi bagaimana PCE dapat mempengaruhi perilaku pembelian ramah lingkungan, karena masalah penyelamatan lingkungan adalah sebuah dilema sosial yaitu sebuah situasi dimana kebaikan bersama dapat tercapai jika hampir dari semua anggota komunitas mau berkorban (Wiener dan Doescher, 1991).

Hipotesis 3 pada penelitian ini tidak terdukung. Hasil pengujian hipotesis menunjukkan bahwa kepedulian lingkungan tidak berpengaruh pada perilaku pembelian ramah lingkungan. Lebih lanjut, peneliti melakukan in-depth interview kepada sepuluh orang informan yang sebelumnya menjadi responden dalam penelitian ini, dimana in-depth interview ini bertujuan untuk mengetahui lebih dalam pendapat dan alasan dari informan mengenai tidak terdukungnya hipotesis 3 pada penelitian ini. Responden yang dijadikan sebagai informan merupakan responden yang menurut peneliti dapat memberikan informasi yang jelas dan berkualitas. Alasan yang disampaikan oleh mereka adalah kebanyakan dari mereka peduli terhadap lingkungan yang akan menjadi tepat tinggal bagi keturunannya di masa yang akan datang, tetapi daya 
beli mereka terhadap produk yang ramah lingkungan masih kurang karena harga yang lebih mahal dibandingkan dengan produk biasa.

Dari hasil analisis maka variabel yang paling dominan pengaruhnya perilaku pembelian ramah lingkungan adalah variabel kolektivisme dibandingkan dengan variabel lainnya, hal ini karena kolektivisme memiliki nilai t-hitung paling besar positif $(2,486)$ dengan demikian kolektivisme merupakan faktor pendorong utama bagi karyawan untuk meningkatkan perilaku pembelian ramah lingkungan. Hal ini mungkin disebabkan karena penelitian ini di lakukan di Indonesia yang sebagian besar penduduknya masih memegang budaya kolektivisme dalam keseharian mereka.

\section{H. KESIMPULAN}

Adapun temuan dari penelitian ini dapat disimpulkan sebagai berikut:

1. Terdapat pengaruh kolektivisme yang signifikan terhadap perilaku pembelian ramah lingkungan. Mereka yang mempunyai jiwa kolektivime akan lebih bertanggung jawab pada kepedulian lingkungan.

2. Terdapat pengaruh Perceived Consumer Effectiveness yang signifikan terhadap perilaku pembelian ramah lingkungan. Konsumen merasa dapat membuat sebuah perbedaan dan dapat mememecahakan masalah yang berkaitan dengan lingkungan hidup ketika mereka melakukan pembelian produk yang ramah lingkungan dibandingkan dengan produk yang biasa.

3. Tidak terdapat pengaruh kepedulian lingkungan yang signifikan terhadap perilaku pembelian ramah lingkungan. Konsumen merasa perilaku mereka menjaga lingkungan mereka (misal, daur ulang) sudah cukup berdampak pada kondisi lingkungan hidup. Konsumen tidak sampai pada taraf melakukan pembelian produk yang ramah lingkungan karena mereka menganggap bahwa produk ramah lingkungan lebih mahal dan kualitasnya juga tidak terlalu bagus.

\section{DAFTAR PUSTAKA}

Alibeli, A. and C. Johnson (2009), "Environmental Concern: A Cross National Analysis," Journal of International and Cross-Cultural Studies, Vol 3, No 1, pp. 1-10.

Arimbi, H.P. (2003). "Gerakan Konsumen Hijau di Indonesia, " diakses dari http://members.fortunecity.com/lingkungan/artikel/GeerakanKHijau.htm. pada tanggal 28 April 2011

Bamberg, S and G. Moser (2007), "Twenty Years After Hines, Hungerford, and Tomera: A New Meta-Analysis of Psycho-social Determinants of ProEnvironmental Behaviour," Journal of Environmental Psychology, Vol 27, pp. $14-25$.

Chase, D dan T.K. Smith (1992), "Consumers Keen on Green but Marketers Don't Deliver," Advertising Age, 63 (June 29), s2-s4. 
Davidson, D.J. and W.R. Freudenburg (1996), "Gender and Environmental Risk Concerns: A Review and Analysis of Available Research," Environmental Behavior, Vol 28, No 3, pp. 302-39.

De Abreu, M.C. and J.C. Lins (2010), "A Demographic Analysis of Consumer Environmental Attitudes about Liquefied Petroleum Gas in Brazil," Electronic Journal of Business Ethics and Organization Studies, Vol 15, No 2, pp. 6-14.

Dharmmesta, B.S. (1997), "Pergeseran Paradigma Dalam Pemasaran: Tinjauan Manajerial dan Perilaku Konsumen," Kelola, No. 15/VI, hal. 12-23.

Dianmantopoulos, A., B.B Schlegelmilch, R.R Sinkovics, and G.M. Bohlen (2003), “ Can Socio-Demographic Still Play A Role in Profiling Green Consumers? A Review of Evidence and An Empirical Investigation," Journal of Bussiness Research, Vol 56, pp. 465-480.

Ellen P.S., J.L. Wiener, dan C.C. Walgren (1991), "The Role of Perceived Consumer Effectiveness in Motivating Environmentally Conscious Behaviors," Journal of Public Policy \& Marketing, Vol. 10, No. 2, pp. 102-117

Ellen, P.S., J.L. Wiener, and C. Cobb-Walgren (1991), "The Role of Perceived Consumer Effectiveness in Motivating Environmentally Conscious Behaviors," Journal of Public Policy \& Marketing, Vol 10, pp. 102-117.

Fotopoulos, C. and A. Krystallis (2002), "Purchasing motives and profile of the Greek organic consumer: a countrywide survey," British Food Journal, Vol 104, No 9, pp.730-765.

Green Consumers: An Exploratory Study of Consumers in India," Journal of International Consumer Marketing, Vol 18, No 3, pp. 107-146.

Grimm, S.D., A.T. Church, M.S. Katigbak, dan J.A.A. Reyes (1999), "Self-Described Traits, Values, and Moods Associated with Individualism and Collectivism: Testing I-C Theory in an Individualistic (U.S.) and a Collectivistic (Philippine) Culture," Journal of Cross-Cultural Psychology, Vol 30, pp.466-500.

Haley, Russell I. (1995), “ Benefit Segmentation: A Decision-Oriented Research Toll," in B.M Enis and K.K. Cox (Eds), Marketing Classics: A Selection of Influencial Articles, $7^{\text {th }}$ ed. Boston, MA: Allyn and Bacon

Hine, D.W. and R. Gifford (1991), "Fear Appeals, Individual Differences, and Environmental Concern," The Journal of Environmental Education, Vol 23, No 1 , pp. 36-41.

Hines, J.M., H.R. Hungerford, and A.N. Tomera (1986), “ Analysis and Synthesis of Research and Responsible Environmental Behavior: A Meta-Analysis," Journal of Environmental Education, Vol 18, No 2, pp. 1-8.

Hume, S.(1991), "Consumer Doubletalk Makes Companies Wary," Advertising Age, 62 (October 28), GR4.

Pengaruh Kolektivisme, Perceived Consumer Effectiveness, dan Kepedulian Lingkungan Terhadap Perilaku Pembelian Ramah Lingkungan (Tri Widodo, Rina Sari Qurniawati) 
Jain, S.K. and G. Kaur (2006),"Role of Socio-Demographics in Segmenting and Profiling," Journal of International Consumer Marketing, Vol. 18, No. 3, pp.107-146.

Junaedi, M.F. (2003), “Analisis Faktor Demografi, Akses Media dan Sumber Informasi Terhadap Kepedulian dan Kesadaran Lingkungan Konsumen: Kajian Pemasaran yang Berwawasan Sosial,". Kinerja, Vol 7, No 2, pp. 99111.

Junaedi, M.F. (2008), “ Pengaruh Gender Sebagai Pemoderasi Pengembangan Model Perilaku Konsumen Hijau di Indonesia,” Kinerja, Vol 12, No 1, pp. 17-37.

Kalantari, K., H.S. Fami, A. Asadi and H.M Mohammadi (2007), "Investigating Factors Affecting Environmental Behavior of Urban Residents: A Case Study in Tehran City- Iran," American Journal of Environmental Sciences, Vol. 3, No 2, pp. 67-74.

Kaplan, S. (2000), "Human nature and environmentally responsible Behavior," Journal of Social Issues, 56, 491-508.

Kasali, R. (2000), Membidik Pasar Indonesia , Segmentasi Targeting Positioning, ed 1. Jakarta: Penerbit PT Gramedia Pustaka Utama.

Kim Y., dan S.M. Choi (2005), "Antecedents of green purchase behavior: An examination of Collectivism, Environmental Concern, and PCE," Advances in Consumer Research, Vol. 32,pp. 592-599

Kim, Y and S.M Choi (2005), "Antecedents of Green Purchase Behavior: An Examination of Collectivism, Environmental Concern, and PCE," Advance in Consumer Research, Vol 32, pp. 592-599.

Kinnear, T.C., J.R. Taylor, and S. A. Ahmed (1974), "Ecologically Concerned Consumers: Who Are They?," The Journal of Marketing, Vol 38, No 2, pp. 20-24.

Laroche, M., J. Bergeron, and G. Barbaro-Forleo (2001), "Targeting Consumers Who Are Willing to Pay More for Environmentally Friendly Products," Journal of Consumer Marketing, Vol 18, No 6, pp. 503-520.

Lee, K. (2009), “Gender Differences in Hong Kong Adolescent Consumers' Green Purchasing Behavior," Journal of Consumer Marketing, Vol 26, No 2, pp. 8796.

McCarthy, J.A. dan L.J. Shrum (1994), "The Recycling of solid wastes: personal values, value orientation, and attitudes about recycling as antecedents of recycling behavior," Journal of Business Research, Vol. 30, No. 1, pp. 53-62.

Mostafa, M.M. (2007), “Gender Differences in Egyptian Consumers' Green Purchase Behaviour: The Effects of Environmental Knowledge, Concern and Attitude," International Journal of Consumer Studies, Vol 31, pp. 220-229. 
Reitman, V. (1992), “Green Products Sales Seem to Be Wilting," The Wall Street Journal, May 18, B1.

Samdahl, D.M. and R. Robertson (1989), “ Social Determinants of Environmental Concern: Specification and Test of The Model," Environment and Behavior, Vol 21, No 1, pp. 57-81.

Shrum, L.J., J.A. McCarthy, and T.M. Lowrey (1994), “ Buyer Characteristics of The Green Consumer and Their Implication of Advertising Strategy," Journal of Advertising, Vol 24, No 2, pp. 71-82.

Starr, M.A. (2009), "The Social Economics of Ethical Consumption: Theoretical Considerations and Empirical Evidence," The Journal of Socio-Economics, Vol 38, pp. 916-925.

Straughan, R.D. (1999), "Environmental segmentation alternative: a look at green consumer behavior in the new millennium," Journal of Consumer Marketing, Vol. 16, No. 5, pp. 558-575.

Straughan, R.D. and J.A. Roberts (1999), "Environmental Segmentation Alternatives: A Look at Green Consumer Behavior in the New Millennium, "Journal of Consumer Marketing, Vol 16, No 6, pp. 558-575.

Tantawi, P. (2009), "Green Consciousness of Consumers in a Developing Country: A Study of Egyptian Consumers," Contemporary Management Research, Vol 5, No 3, pp. 29-50.

Tantawi, P., O'Shaughnessy, N., \& Gad, K. (2006). Obstacles of Going Green in Egypt. Singapore: paper presented at International Conference on Business and Information.

Thompson, S.C. (1981), "Will It Hurt Less If I Can Control It? A Complex Answer to a Simple Question,” Advances in Consumer Research, Vol. 9, pp. 306-312.

Wagner, S.A. (1997), Understanding Green Consumer Behavior, $1^{\text {st }}$ ed. New York: Routledge.

Wiener, J.L. dan T.A. Doescher( 1991), "A Framework for Promoting Co-operation," Journal of Marketing, (April),3 8-47. 